\title{
STEMFLOW NUTRIENT INPUT IN TREES IN A TROPICAL FOREST IN PERNAMBUCO, BRAZIL
}

\author{
Yasmim Yathiara Gomes Araújo Morais ${ }^{1 *}$, Fernando José Freire², Rosival Barros de Andrade Lima1 ${ }^{1}$, Edilane \\ Alice de Alcântara Assunção ${ }^{1}$, Shyrlaine Lilian Moura Leão ${ }^{1}$, Lidiana Nayara Ralph ${ }^{1}$ \\ ${ }^{1 *}$ Universidade Federal Rural de Pernambuco, Departamento de Ciência Florestal, Recife, Pernambuco, Brasil - e-mail: \\ yasmimyathiara@gmail.com*; rosival_barros@yahoo.com.br; aliceedilane2@gmail.com; shyrlaine.leao@gmail.com; \\ lidianaralph@gmail.com \\ ${ }^{2}$ Universidade Federal Rural de Pernambuco, Departamento de Agronomia, Recife, Pernambuco, Brasil - e-mail: \\ fernandojfreire@uol.com.br
}

Received for publication: 01/02/2020 - Accepted for publication: 31/03/2020

\begin{abstract}
Resumo
Aporte de nutrientes via escoamento pelo tronco de espécies arbóreas em floresta tropical, Pernambuco, Brasil. A precipitação pluviométrica é a principal entrada de água nos ecossistemas florestais e o escoamento pelo tronco uma importante via de entrada de nutrientes nesses ecossistemas. Dessa forma, esse estudo teve como objetivo avaliar a precipitação efetiva em fragmento de floresta tropical e o aporte de nutrientes via escoamento pelo tronco de espécies arbóreas em diferentes períodos de precipitação pluviométrica. A precipitação total e a precipitação interna foram mensuradas utilizando pluviômetros no interior e na borda do fragmento. Com base em levantamento fitossociológico foram escolhidas nove espécies com maior densidade absoluta no fragmento e selecionados três indivíduos, onde foram fixados coletores ao redor do tronco deles para coleta da água proveniente do escoamento pelo tronco. A água do escoamento pelo tronco foi medida em mililitros, mensurado o $\mathrm{pH}$, a condutividade elétrica e determinado o aporte de $\mathrm{K}, \mathrm{P}$ e $\mathrm{Na}$. Com base na precipitação interna e escoamento pelo tronco foi calculada a precipitação efetiva. $\mathrm{O}$ aporte de nutrientes proveniente do escoamento pelo tronco apresentou a seguinte ordem decrescente: $\mathrm{Na}>\mathrm{K}>\mathrm{P}$. O elevado aporte de $\mathrm{Na}$ pode ser explicado pelo fragmento encontrar-se próximo a área litorânea. $\mathrm{O}$ escoamento pelo tronco das espécies florestais mostrou-se importante via de entrada de nutrientes nos ecossistemas florestais, participando efetivamente da ciclagem de nutrientes.

Palavras-chave: Ciclagem de nutrientes; Mata Atlântica; Precipitação pluviométrica.
\end{abstract}

\begin{abstract}
Rainfall is the main source of water in forest ecosystems and stemflow is an important pathway for nutrients to enter these ecosystems. Thus, this study aimed to evaluate effective precipitation in a fragment of tropical forest and stemflow nutrient input of tree species in different periods of rainfall. Total precipitation and throughfall were measured using rain gauges inside and at the edge of the fragment. After a phytosociological survey, nine species with the highest absolute density in the fragment were chosen and three individuals were selected. Water collectors were fixed around their trunk to collect stemflow water. The stemflow water was measured in milliliters, and $\mathrm{pH}$, electrical conductivity and the input of $\mathrm{K}, \mathrm{P}$ and $\mathrm{Na}$ were determined. Based on the throughfall and stemflow, the effective precipitation was calculated. The stemflow nutrient input presented the following decreasing order: $\mathrm{Na}>\mathrm{K}>\mathrm{P}$. The high input of $\mathrm{Na}$ can be explained by the fact that the fragment is close to the coastal area. Stemflow of forest species proved to be an important pathway for nutrients to enter forest ecosystems, effectively participating in nutrient cycling.

Keywords: Nutrient cycling; Atlantic forest; Rainfall.
\end{abstract}

\section{INTRODUCTION}

The hydrological cycle is responsible for the movement of rainwater and the changes that occur during its movement (QUEIROZ; OLIVEIRA, 2013). Rainfall in forest ecosystems can follow two routes: return to the atmosphere through evapotranspiration or reach the surface of the soil through stemflow (FREITAS et al., 2016).

Rainfall is the main source of water input into forest ecosystems, effectively participating in the hydrological cycle. Some factors such as solar radiation, gravity and terrestrial rotation will influence the flow of water generated by the interaction between the surface and the atmosphere (UCHIYAMA et al., 2018). Quantifying the rainfall patterns of different regions provides relevant information that helps in the management of water resources and in the conservation of soils and forests (JOHNSON; GREEN, 2018).

Hydrological pathways in forest ecosystems are responsible for connecting the atmosphere, vegetation and soil compartments, in addition to being an important source of nutrient input. The hydrological regime has an influence on the amount of water that will enter the ecosystems. However, it is the path that the water will take that will determine its chemical composition and its contribution to the cycling of nutrients (GERMER et al., 2010).

FLORESTA, Curitiba, PR, v. 51, n. 3, p. 604-613, jul/set 2021.

Morais, Y. Y. G. A. et.al.

ISSN eletrônico 1982-4688

DOI: $10.5380 /$ rf.v51 i3. 71464 
The variability and heterogeneity of the distribution of rainfall and stemflow in the fragments and, consequently, in the cycling of nutrients, is influenced by the great diversity of species in tropical forests, which can cause a high incidence of drippoints (MOURA et al., 2012).

Studying the different forms of nutrient entry into forest ecosystems, especially in tropical forests, is of great value, since they are environments that generally have low nutritional reserves and/or acidic soils (CHANG et al., 2017). The cycling of nutrients through rainfall and stemflow occurs because of the entry of nutrients that are in the atmosphere. The species retain in their leaves particles that are carried by the wind. These particles contain nutrients. When rainfall occurs, these particles are leached from the surface of the leaves, run down the trunk and the nutrients contained in them are added to the soil (DINIZ et al., 2013). Thus, this study tested the following hypothesis: the entry of nutrients via stemflow should differ by species and by the seasonal difference in the amount of water that is precipitated in the ecosystem, contributing significantly to nutrient cycling.

To test this hypothesis, the study aimed to evaluate the effective precipitation in a tropical forest fragment and stemflow nutrient input of tree species in different periods of rainfall.

\section{MATERIAL AND METHODS}

\section{Characterization of the area}

The study was carried out in a remnant of the Atlantic Forest, located in the municipality of Sirinhaém, Pernambuco, Brazil. The forest typology in the fragment is the Dense Ombrophilous Forest of the Lowlands. The area has 42 ha, and is located between the geographic coordinates (UTM 25L) Latitude: 263220. 263849, 263544 and 263967, and Longitude: 9054184, 9054442, 9053691 and 9053725, belonging to Usina Trapiche S/A (Figure $1)$.
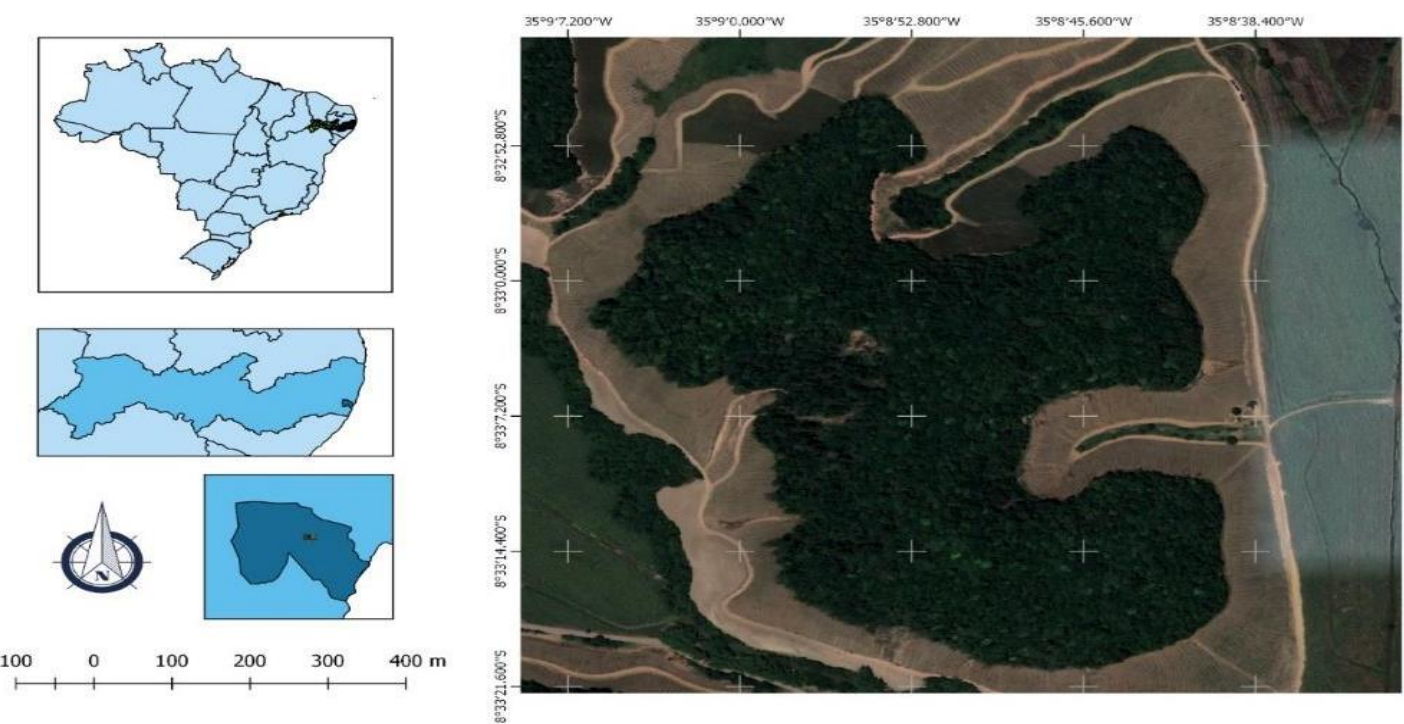

Figure 1. Geographic location of the fragment, in the municipality of Sirinhaém, Pernambuco, Brazil.

Figura 1. Localização geográfica do fragmento no município de Sirinhaém, Pernambuco, Brasil.

According to the Köppen classification (ALVARES et al., 2013), the region has a monsoon climate, (Am) with an average annual temperature of around $25.6^{\circ} \mathrm{C}$. The rainy season extends from April to September (APAC, 2020). The average altitude is $60 \mathrm{~m}$ and the soils that predominate in the area are of the type: Yellow Latosol; Yellow Argisol; Red-Yellow Argisol; Grayish Argisol; Gleysol; Cambisol and Fluvic Neosol (EMBRAPA, 2018).

\section{Climatic periods}

The study was carried out from March to August 2019, a period characterized by the highest incidence of rainfall in the Zona da Mata of Pernambuco. According to APAC (2020), in this period, the accumulated rainfall in Sirinhaém was $1,800.2 \mathrm{~mm}$ and the average temperature ranged from $28.5^{\circ} \mathrm{C}$ to $25.7^{\circ} \mathrm{C}$ (Figure 2).

Based on rainfall data, the rainy season in this region was divided into two periods: less rainy (March to May/2019) and more rainy (June to August/2019). 


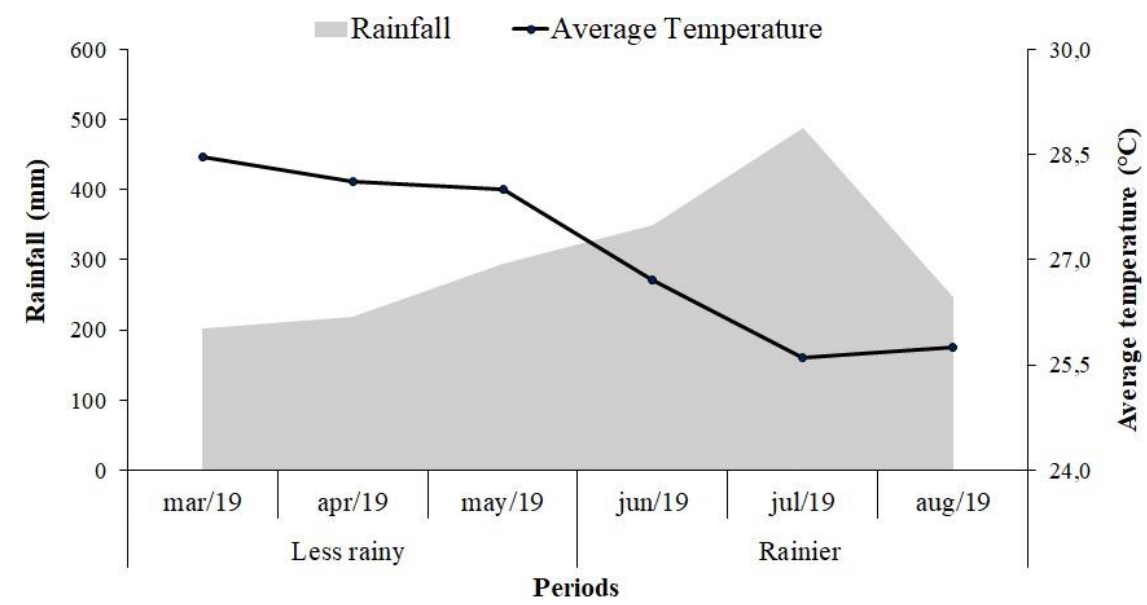

Figure 2. Monthly rainfall and average temperature during the experimental period and definition of the rainier and less rainy periods from March to August/2019, in Sirinhaém, Pernambuco, Brazil.

Figura 2. Precipitação mensal e temperatura média durante o período experimenta e definição dos períodos mais e menos chuvosos de março a agosto/2019, em Sirinhaém, Pernambuco, Brasil

\section{Forest Species}

Based on the phytosociological survey carried out by Lima et al. (2018), 40 plots of $10 \mathrm{~m}$ x $25 \mathrm{~m}$ were installed and the nine tree species that showed the highest absolute densities (AD) in the fragment were determined (Table 1).

Table 1. Species with higher absolute density (AD) and average diameter at breast height (DBH) in the fragment of the Dense Ombrophilous Forest of the Lowlands, in Sirinhaém, Pernambuco, Brazil.

Tabela 1. Espécies com maior densidade absoluta (DA) e diâmetro à altura do peito (DAP) médio no fragmento de Floresta Ombrófila Densa das Terras Baixas, em Sirinhaém, Pernambuco, Brasil.

\begin{tabular}{|c|c|c|c|c|}
\hline Species & Family & $\underset{(\text { Ind ha }}{\text { AD }}$ & $\begin{array}{c}\text { Average } \\
\text { Height } \\
\text { (m) }\end{array}$ & $\begin{array}{c}\text { Average } \\
\text { DBH } \\
(\mathbf{c m})\end{array}$ \\
\hline Thyrsodium spruceanum Benth. & Anacardiaceae & 246 & 8.17 & 0.34 \\
\hline Protium heptaphyllum (Aubl.) Marchand & Burseraceae & 134 & 8.90 & 0.44 \\
\hline Tapirira guianensis Aubl. & Anacardiaceae & 68 & 11.77 & 0.69 \\
\hline Eschweilera ovata (Cambess.) Mart. ex Miers & Lecythidaceae & 52 & 7.00 & 0.30 \\
\hline Myrcia sylvatica (G.Mey.) DC. & Myrtaceae & 43 & 6.72 & 0.22 \\
\hline Brosimum rubescens Taub. & Moraceae & 39 & 5.97 & 0.23 \\
\hline Helicostylis tomentosa (Poepp. \& Endl.) Rusby & Moraceae & 36 & 8.34 & 0.30 \\
\hline Casearia javitensis Kunth & Salicaceae & 35 & 6.37 & 0.24 \\
\hline Schefflera morototoni (Aubl). Maguire et al. & Araliaceae & 33 & 11.15 & 0.50 \\
\hline$\sum$ of individuals & - & 686 & - & - \\
\hline
\end{tabular}

\section{Total precipitation and throughfall}

Total precipitation (TP) was recorded by installing an interceptometer, approximately $200 \mathrm{~m}$ outside the forest fragment (Figure 3a). To measure throughfall (TF), two interceptometers were installed under the canopy in the central area of the fragment. 


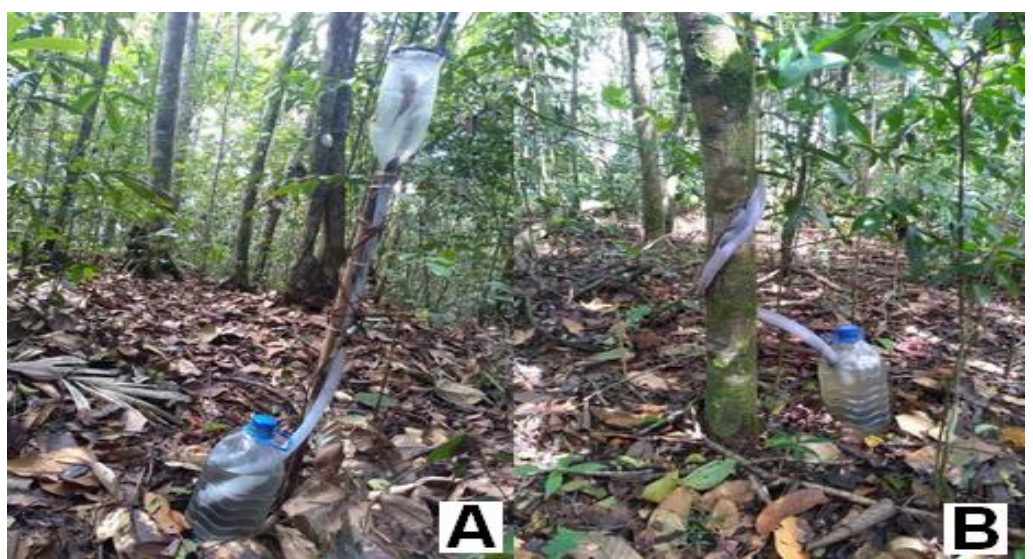

Figure 3. Collector system used to capture rainfall (a) and stemflow (b) of forest species in the fragment of the Dense Ombrophilous Forest of the Lowlands, in Sirinhaém, Pernambuco, Brazil.

Figura 3. Sistema coletor utilizado para capturar a precipitação (a) e escoamento pelo tronco (b) de espécies florestais no fragmento de Floresta Ombrófila Densa das Terras Baixas, em Sirinhaém, Pernambuco, Brasil.

The interceptometers used consisted of a collecting funnel made out of PET bottles and a reservoir with capacity to store $5 \mathrm{~L}$ of water, installed at $1.5 \mathrm{~m}$ above the surface of the soil. Data collection was performed monthly, measured in milliliters using a $1000 \mathrm{~mL}$ graduated cylinder. The amount of TP and TF was calculated, according to Diniz et al. (2013), using the expression:

$$
h=\left(\frac{V}{S}\right) \times 10
$$

where: $\mathrm{h}$ is the height of the precipitated water layer $(\mathrm{mm}) ; \mathrm{V}$ is the volume of rainwater $\left(\mathrm{cm}^{3}\right) ; \mathrm{S}$ is the funnel opening area $\left(\mathrm{cm}^{2}\right)$; and 10 is a factor for adjusting units.

\section{Stemflow and effective precipitation}

The quantification of stemflow (SF) was carried out in both periods: in the less rainy period and in the more rainy period, from March to August/2019, in the nine species that presented higher AD in the fragment. Three individuals of each species were selected, with a total of 27 collectors. These individuals selected had a diameter at breast height (DBH) similar to the mean DBH of all individuals of that species (Table 1).

For this, a collecting system was fixed around the trunk of the individuals selected, using a 1-inch plastic hose, cut in the longitudinal direction. A collecting chute was formed in order to capture the drained water. The collecting chutes were fixed in a spiral shape, following the circumference of the tree trunks. The material was fixed with nails and sealed with silicone glue. The captured rainwater was directed to plastic containers with the capacity to store up to $5 \mathrm{~L}$ of water. The containers were positioned vertically and fixed to the ground (Figure $3 \mathrm{~b}$ ). These methodological procedures were adapted from Moura et al. (2009).

The SF water was measured in milliliters using a $1000 \mathrm{~mL}$ graduated cylinder and, subsequently, an aliquot was taken to analyze the chemical composition of the water. The $\mathrm{pH}$, electrical conductivity (EC), K, P and $\mathrm{Na}$ values were determined. $\mathrm{Na}$ and $\mathrm{K}$ have been studied because in coastal areas, many salts of $\mathrm{Na}$ and $\mathrm{K}$ are reported, to the detriment of $\mathrm{Ca}$ and $\mathrm{Mg}$, in addition to the high leaching capacity of these elements because of their high solubilities. $\mathrm{P}$ was studied because the soil of the fragment was very poor in $\mathrm{P}$ and the stemflow input can be a very important route in the cycling of this nutrient. $\mathrm{K}$ and $\mathrm{Na}$ were determined using a flame photometer and $\mathrm{P}$ by the colorimetric method (TEDESCO et al., 1995).

The conversion of SF into millimeters of water was performed by averaging the volume stored in the reservoirs and a conversion factor equal to $14.58 \mathrm{~m}^{2}$. The conversion factor was calculated as a function of population density and estimated by dividing the size of the experimental area by the number of individuals of the nine species selected (Table 1), according to Silva et al. (2018). By obtaining the TF and SF data, it was possible to calculate the effective precipitation (EP), according to Diniz et al. (2013), through the equation:

$$
E P=T F+S F
$$

where: EP is the effective precipitation (mm); TF is the throughfall (mm); SF is the stemflow (mm).

FLORESTA, Curitiba, PR, v. 51, n. 3, p. 604-613, jul/set 2021. 
To measure SF by species in each period $\left(\mathrm{L} \mathrm{ha}^{-1}\right)$, the average SF in liters of individuals of the species was obtained and multiplied by the number of individuals of the species per hectare. The total SF per period was calculated by adding the SF of the species.

Because of the limited capacity of the containers placed to store SF water, it was observed that in some rainy events the containers overflowed. The storage capacity of the containers was estimated based on historical averages of rainfall. However, in the month of July 2019, rains exceeded historical averages (Figure 2), causing some containers to overflow. According to Lorenzon et al. (2015), when the containers overflow, an underestimation of the SF capacity of the species may occur, suggesting that this water intake may be much greater. However, as the study had monitored three individuals per species in each period, the container where the overflowing occurred was eliminated.

\section{Statistical analysis}

The data were tested for normality and homoscedasticity, assumptions necessary for the analysis of variance (ANOVA), using the Shapiro-Wilk (SHAPIRO; WILK, 1965) and Levene (BROWN; FORSYTHE, 1974) tests, respectively, both with a probability level of 5\%. Subsequently, analysis of variance (ANOVA) was performed on the data of SF, pH, EC and K, P and Na input, considering the F test at the probability level of $5 \%$. When significance was observed between the main effects and/or the interactions, the means were compared using the Scott-Knott test at 5\% probability. When the coefficients of variation (CV) showed values greater than 30 , the data transformation was performed $(\sqrt{X}+1)$. The software ASSISTAT 7.7 was used to perform statistical analyses (SILVA; AZEVEDO, 2016).

\section{RESULTS}

During the study period, a total precipitation of 1,800.2 $\mathrm{mm}$ was recorded in the municipality of Sirinhaém (Figure 2), however, in the fragment there was a total precipitation of 1,352.2 mm, of which $29.57 \%(399,9 \mathrm{~mm})$ were recorded in the less rainy season and $70.43 \%(952.3 \mathrm{~mm})$ in the rainier season (Figure 4).

Throughfall (TF) was higher than the total precipitation (TP) in the fragment in the less rainy period, showing a difference of $110.7 \mathrm{~mm}$ in relation to TP. However, in the rainier period the opposite occurred, TP was $18.1 \mathrm{~mm}$ higher than TF (Figure 4).

Regarding the stemflow (SF), it is noted that in relation to the periods, the increase from one period to another was minimal, representing a small fraction of the TP, being $0.59 \mathrm{~mm}$ for the less rainy period and 0.69 $\mathrm{mm}$ for the rainier (Figure 4). The rainier period presented an effective precipitation (EP) of 54.68\% higher than the less rainy period and represented $98.17 \%$ of the TP of that period (Figure 4).

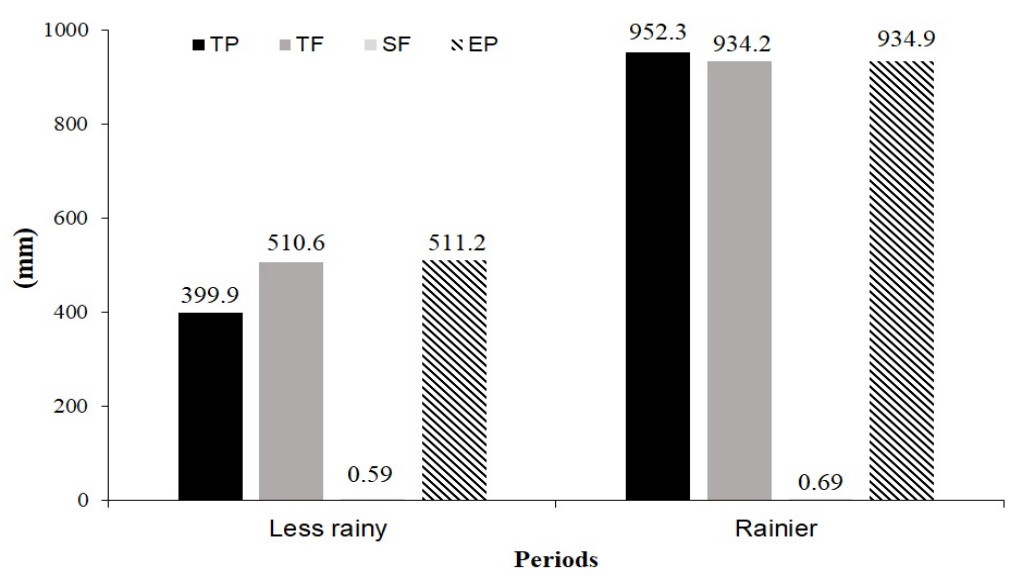

Figure 4. Total precipitation (TP), Throughfall (TF), Stemflow (SF) and Effective precipitation (EP) in different rainfall periods in a fragment of the Dense Ombrophilous Forest of the Lowlands, in Sirinhaém, Pernambuco, Brazil.

Figura 4. Precipitação total (PT), Precipitação interna (PI), Escoamento pelo tronco (ET) e Precipitação efetiva (PE) em diferentes períodos pluviométricos em um fragmento de Floresta Ombrófila Densa das Terras Baixas, em Sirinhaém, Pernambuco, Brasil.

During the study period, the SF of all species was $1,990.36$ and 2,359.29 $\mathrm{L} \mathrm{ha}^{-1}$ for the less rainy and rainier periods, respectively (Figure 5). SF differed between species, which showed the same behavior regardless of the study period. SF was higher in the rainiest period, except for the SF of Helicostylis tomentosa which showed 
a different behavior in comparison to the other species. In the less rainy period, this species showed a higher SF when compared to the rainier one, with 116.88 and $110.12 \mathrm{~L} \mathrm{ha}^{-1}$, respectively (Figure 5).

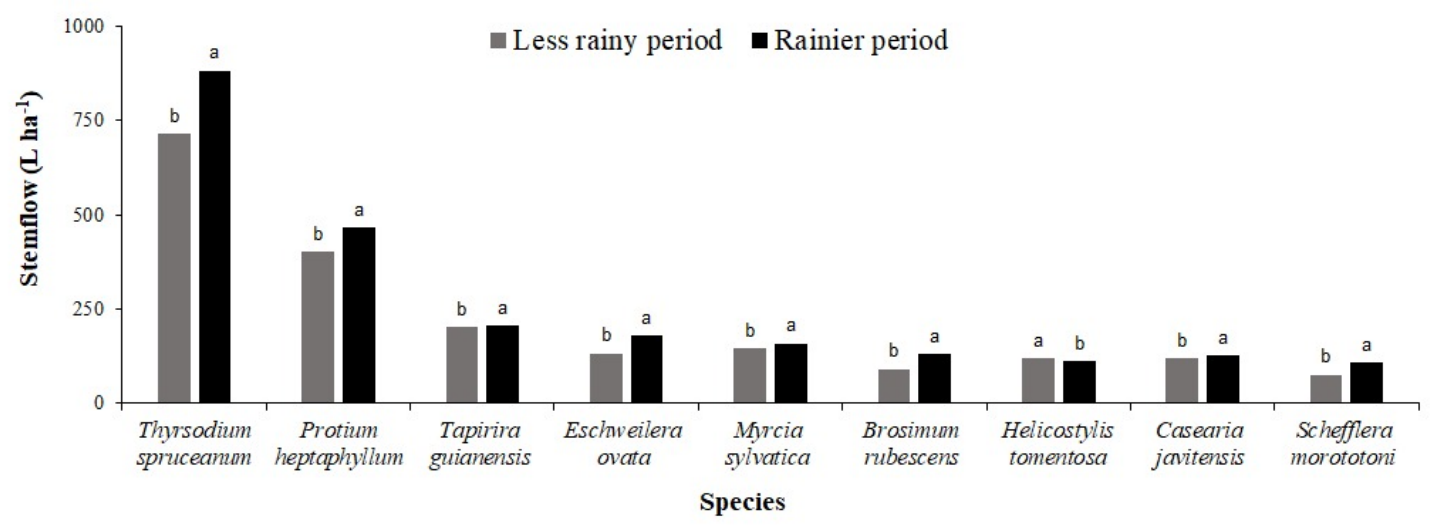

Figure 5. Stemflow of forest species in different periods of rainfall in a fragment of the Dense Ombrophilous Forest of the Lowlands, in Sirinhaém, Pernambuco, Brazil.

Figura 5. Escoamento pelo tronco de espécies florestais em diferentes períodos pluviométricos em um fragmento de Floresta Ombrófila Densa das Terras Baixas, em Sirinhaém, Pernambuco, Brasil.

Thyrsodium spruceanum was the species that presented the highest SF in both periods, with 714.08 and 882.87 $\mathrm{L} \mathrm{ha}^{-1}$, for the less rainy and rainier periods, respectively. Schefflera morototoni and Brosimum rubescens showed less stemflow in the less rainy period, however, for the rainier one, only Schefflera morototoni showed less stemflow (Figure 5).

The SF nutrient input followed the following decreasing order: $\mathrm{Na}>\mathrm{K}>\mathrm{P}$ (Table 2). $\mathrm{Na}$ input via SF showed an interaction between species and period. For K, there was only difference between species. And, for $\mathrm{P}$ there was a difference between species and periods (Table 2).

Table 2. Stemflow nutrient input, $\mathrm{pH}$ and electrical conductivity of the stemflow water of the different forest species in a fragment of the Dense Ombrophilous Forest of the Lowlands, in Sirinhaém, Pernambuco, Brazil.

Tabela 2. Aporte de nutrientes via escoamento pelo tronco, $\mathrm{pH}$ e condutividade elétrica da água do escoamento das diferentes espécies florestais em fragmento de Floresta Ombrófila Densa das Terras Baixas, em Sirinhaém, Pernambuco, Brasil.

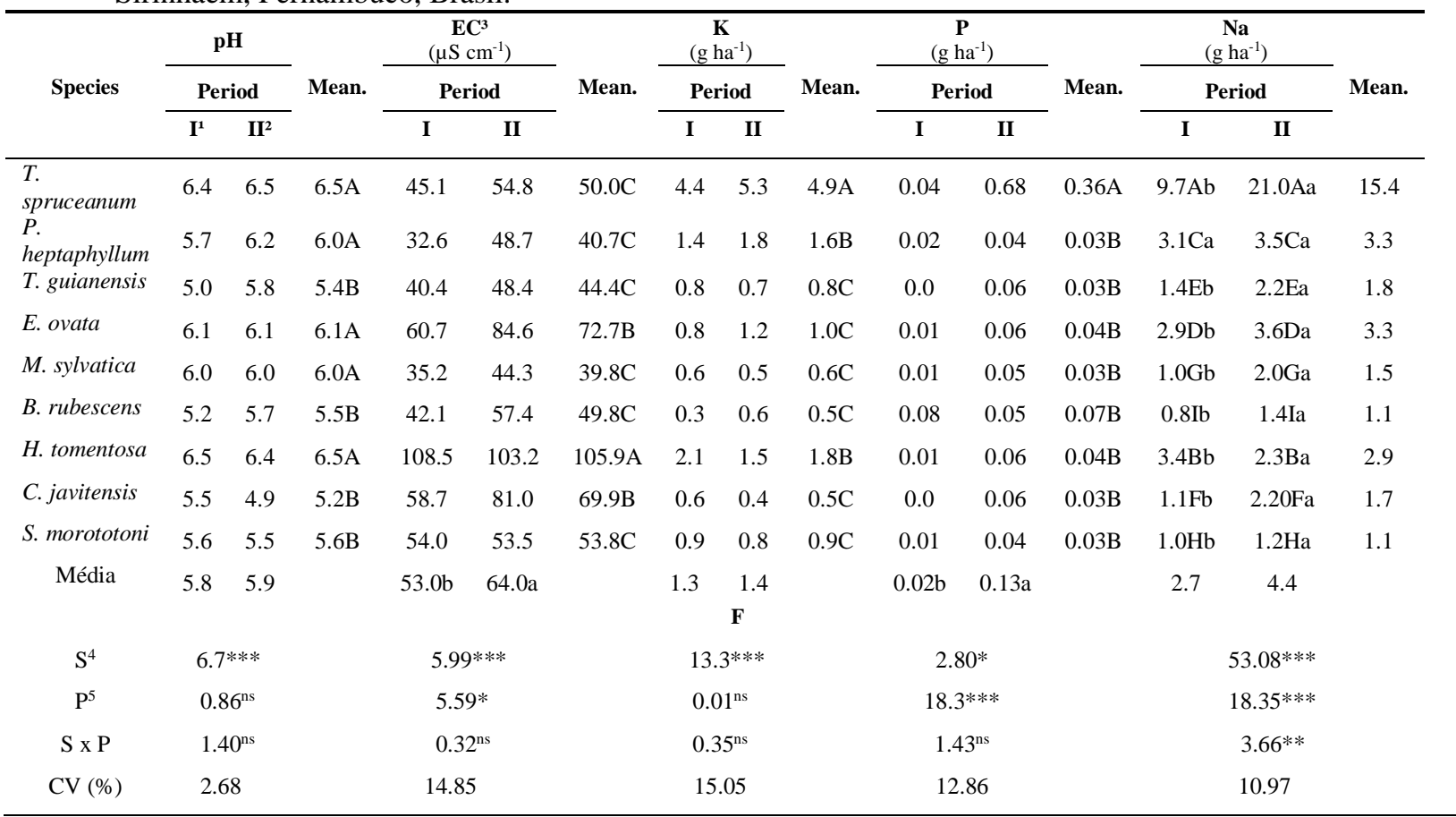

1'Less rainy period; ${ }^{2}$ Rainier period; ${ }^{3}$ Electric conductivity; ${ }^{4}$ Species; ${ }^{5}$ Period.

Similar means followed by lowercase letters in the lines and uppercase letters in the columns did not differ by the F and Scott-Knott test at $5 \%$ probability. *, ** and $* * *$ significant at 5,1 and $0.1 \%$ probability,respectively. ${ }^{\text {ns }}$ not significant. 
$\mathrm{Na}$ input showed an average among the species of $3.5 \mathrm{~g} \mathrm{ha}^{-1}$ and a variation of 1.10 to $15.4 \mathrm{~g} \mathrm{ha}^{-1}$. P input occurred in a smaller amount for all species, varying from 0.03 to $0.36 \mathrm{~g} \mathrm{ha}^{-1}$ (Table 2). Thyrsodium spruceanum was the species that most contributed nutrients to the fragment via SF, with 4.9, 0.36 and $15.4 \mathrm{~g} \mathrm{ha}^{-1}$ for K, $\mathrm{P}$ and $\mathrm{Na}$, respectively (Table 2). Species such as Protium heptaphyllum, Eschweilera ovata, Brosimum rubescens and Helicostylis tomentosa also stood out regarding the SF nutrient input (Table 2).

Regarding $\mathrm{pH}$, variation was observed only between species. However, for EC there was variation between species and between periods (Table 2). Among the species, Helicostylis tomentosa stood out in relation to the others because of its high $\mathrm{pH}$ and EC (Table 2). It was also observed that the yellowish hue of the SF water influenced the higher value of EC, with emphasis on Helicostylis tomentosa and Eschweilera ovata with 105.9 and $72.7 \mu \mathrm{S} \mathrm{cm}^{-1}$, respectively (Table 2; Figure 6).

Of the species that presented the water via yellowish SF, Brosimum rubescences and Helicostylis tomentosa are from the Moraceae family, Thyrsodium spruceanum from the Anacardiaceae family and Eschweilera ovata from the Lecythidaceae family (Table 1; Figure 6).

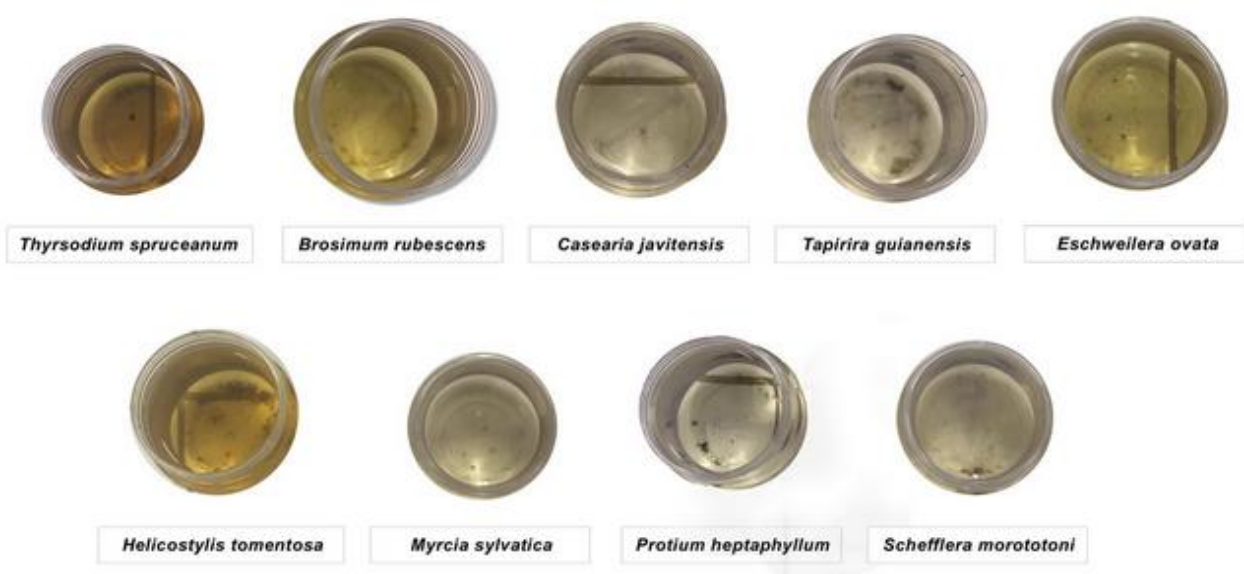

Figure 6. Hue of stemflow water of forest species in a fragment of the Dense Ombrophilous Forest of the Lowlands, in Sirinhaém, Pernambuco, Brazil.

Figura 6. Tonalidade da água do escoamento pelo tronco de espécies florestais em um fragmento de Floresta Ombrófila Densa das Terras Baixas, em Sirinhaém, Pernambuco, Brasil.

\section{DISCUSSION}

The behavior of the variation between TP and TF, especially in the rainiest period observed in this study, was also observed in other studies (MOURA et al., 2009; TONELLO et al., 2014), and can be explained by some factors, among them: distance and altitude difference between the interceptometers (MOURA et al., 2009); higher humidity in the canopies during the rainiest period, allowing maximum storage capacity to be quickly reached, favoring TF (MELO NETO et al., 2019). Additionally, in the less rainy period, the temperature was higher than in the rainier one (Figure 2), causing greater evaporation of the water stored in the interceptometer placed outside the fragment by the direct incidence of the sun, while the interceptometer placed inside the fragment was always protected by the canopies, minimizing the direct effects of the sun. In the rainier period, there was greater uniformity of temperature inside and outside the fragment, reducing the effect of evaporation on the measurement of interceptometers.

Moura et al. (2012), in a study carried out in the Prata basin, in Recife - Pernambuco, Brazil, during two periods, found that the rainy period presented a greater SF when compared to the low rainy period, with 5.3 and $1.0 \mathrm{~mm}$, respectively. The authors reported that the degree of canopy wetting of the trees and the characteristics of the rains, linked to the temperature, humidity of the air, solar radiation and speed of the winds can contribute to the difference between periods.

The EP values found by Tonello et al. (2014) were superior to the results found in this study in the less rainy season. According to these authors, EP is influenced by vegetation cover, with canopies being responsible for cushioning and directing the raindrops, which in turn reach the surface of the soil with less speed, causing less impact.

Helicostylis tomentosa showed different behavior in relation to SF between species, as they are large trees with heights greater than $30 \mathrm{~m}$, with a straight stem and a canopy reaching up to $12 \mathrm{~m}$ (ARRUDA; FERRAZ, 2008). This species was one of those with the highest average height among the species studied in the fragment (Table 1). The height of the individuals, together with the straight shaft in this species, can explain the greater SF

FLORESTA, Curitiba, PR, v. 51, n. 3, p. 604-613, jul/set 2021.

Morais, Y. Y. G. A. et.al.

ISSN eletrônico 1982-4688

DOI: $10.5380 /$ rf.v51 i3. 71464 
in the less rainy period, since the rainwater intercepted by the canopy was easily drained, allowing it to reach the surface of the soil without occurring so many losses in the less rainy period, when compared to the other species. The structural characteristics of crown shape of the species Thyrsodium spruceanum favored the flow of water, as it is a species that has an elongated and open crown, providing greater SF in the less rainy and rainier periods, standing out among all species.

In this study, the hue of the water that flowed down the species stems showed different colors. A factor that may have contributed to this water hue was the leaf morphology, because it is in the leaves that particles coming from the atmosphere loaded with nutrients are attached, and as the rainy events happened, these particles were leached.

Correlations between leaf morphological characteristics that favor this adhesion and the amount of nutrients that run down the stems may adequately explain this difference between species.

The variations found in relation to $\mathrm{pH}$ and EC may have happened, according to Luna-Robles et al. (2019), because as the rainy events happen, the mineral salts that were deposited in the foliage of the trees are leached. The authors found similar EC values to those of this study, in which the species Acacia farnesiana, Leucaena leucocephala and Casimiroa greggii stood out with $155.13,129.10$ and $125.34 \mu \mathrm{S} \mathrm{cm}{ }^{-1}$, respectively.

The considerable stocks of $\mathrm{Na}$ found in the species can be explained by the proximity of the study area to the sea, thus influencing the amount of $\mathrm{Na}$ found in the SF after this element is brought by saline winds from the sea and deposited on the surface of the trees. In addition, these high values can serve as a warning, as they can hinder the initial growth of regenerants in forest fragments near the sea, especially when these regenerants are constituted of species that are not tolerant to salinity.

$\mathrm{K}$ is also frequently transported by winds and is an easily leached nutrient, as it is not present in the structural parts of plant cells. Therefore, high deposition and leaching are expected (DINIZ et al., 2013).

Low concentrations of $\mathrm{P}$ in the water are expected because this nutrient has a low concentration in tropical environments and its cycling occurs predominantly through litterfall deposition (LIMA et al., 2019).

When comparing the stock of nutrients via SF with that found in the leaf biomass in the study carried out in the same fragment and in with the same species by LIMA et al. (2018), it was possible to notice that the contribution of this cycling path is small, but important, mainly for the growth of species in the regenerative extract.

Species such as Myrcia sylvatica and Brosimum rubescens showed lower stocks of P and K (LIMA et al., 2018), which was also observed for the SF in which Brosimum rubescens obtained the lowest K input among all species studied (Table 2 ).

The low concentrations of nutrients found through SF can be explained by the presence of mosses and lichens in the tree trunks, as they end up absorbing the nutrients preventing them from reaching the soil surface (DAWOE et al., 2018).

Although studies quantifying the nutrients present in SF are not frequent, their contribution to the cycling of nutrients in ecosystems is notorious. Luna-Robles et al. (2019) conducting a study in Linares, Mexico, found that the contribution via SF was considerable with 0.80 and $6.40 \%$ of macro and micronutrients, respectively.

\section{CONCLUSION}

- The stemflow of forest species differed by species and had little influence from the rainy season, and proved to be an important pathway for nutrients to enter forest ecosystems, mainly $\mathrm{K}$ and $\mathrm{Na}$, effectively participating in nutrient cycling;

- Species such as Thyrsodium spruceanum, Protium heptaphyllum and Helicostylis tomentosa are indicated for places with low availability of these nutrients, mainly $\mathrm{K}$ because they can input considerable amounts of this nutrient to the ecosystem;

- The stemflow nutrient input presented the following order: $\mathrm{Na}>\mathrm{K}>\mathrm{P}$. The high $\mathrm{Na}$ input can be explained by the fragment being close to the coastal area.

\section{REFERENCES}

ALVARES, C. A.; STAPE, J. L.; SENTELHAS, P. C.; GONÇALVES, J. L. M.; SPAROVEK, G. Köppen's climate classification map for Brazil. Meteorologische Zeitschrift, Stuttgart, v. 22, n. 6, p. 711 - 728, 2013.

AGÊNCIA PERNAMBUCANA DE ÁGUAS E CLIMA (APAC). Boletim do clima: Síntese climática. 2020. Disponível em: 〈http://www.apac.pe.gov.br/meteorologia/monitoramento-pluvio.php>. Acesso em: 13 de janeiro de 2020.

ARRUDA, Y. M. B. C.; FERRAZ, I. D. K. Ilharé-da-folha-peluda, Helicostylis tomentosa (Poepp. \& Endl.) Rusby. In: FERRAZ, I. D. K.; CAMARGO, J. L. C. (Eds.). Manual de sementes da Amazônia. INPA: Manaus - AM. 2008. Fascículo 6. 12p.

FLORESTA, Curitiba, PR, v. 51, n. 3, p. 604-613, jul/set 2021. 
BROWN, M. B.; FORSYTHE, A. B. Robust test for equality of variances. Journal of the American Statistical Association, [S.1.], v. 69, n. 346, p. $364-367,1974$.

CHANG, C. T.; WANG, L.; HUANG, j.; LIU, C.; WANG, C.; LIN, N.; LIN, T. Precipitation controls on nutrients budgets in subtropical and tropical forests and the implications under changing climate. Advances in Water Resources, [S.1.], v. 103, n. 1, p. 44 - 50, 2017.

DAWOE, E. K.; BARNES, V. R.; OPPONG, S. K. Spation-temporal dynamics of gross rainfall partitioning and nutriente fluxes in shaded-cocoa (Theobroma cocoa) systems in a tropical semi-deciduous forest. Agroforestry Systems, [S.1.], v. 92, n. 2, p. $397-413,2018$.

DINIZ, A. R.; PEREIRA, M. G.; BALIEIRO, F. C.; MACHADO, D. L.; MENEZES, C. E. G. Precipitação e aporte de nutrientes em diferentes estádios sucessionais de Floresta Atlântica, Pinheiral - RJ. Ciência Florestal, Santa Maria, v. 23, n. 3, p. 389 - 399, 2013.

EMPRESA BRASILEIRA DE PESQUISA E AGROPECUÁRIA (EMBRAPA). Sistema Brasileiro de Classificação de Solos. 5a. ed., rev. e ampl. Brasília - DF: Embrapa, 2018. 356 p.

FREITAS, J. P. O.; DIAS, H. C. T.; SILVA, E.; TONELLO, K. C. Net precipitation in a semideciduous forest fragment in Viçosa city, MG. Revista Árvore, Viçosa, v. 40, n. 5, p. 793 - 801, 2016.

GERMER, S.; WERTHER, L.; ELSENBEER, H. Have we underestimated stemflow? Lessons from an open tropical rainforest. Journal of Hydrology, [S.1.], v. 395, n. 3 - 4, p. 169 - 179, 2010.

JOHNSON, F.; GREEN, J. A comprehensive continent-wide regionalization investigation for daily design rainfall. Journal of Hydrology: Regional Studies, [S.1.] v. 16, n. 1, p. 67 - 79, 2018.

LIMA, R. B. A.; MARANGON, L. C.; FREIRE, F. J.; FELICIANO, A. L. P.; FREIRE, M. B. G. S.; SILVA, R. K. S.; FREIRE, C. S. Nutritional contribution of litter in Rainforest of Brazil. Journal of Agricultural Science, Ontario, v. 11, n. 3, p. $254-266,2019$.

LIMA, R. B. A.; FREIRE, F. J.; MARANGON, L. C.; FELICIANO, A. L. P. SILVA, R. K. S.; FREIRE, M. B. G. S.; FREIRE, C. S. Nutritional efficiency of plants as an indicator of forest species for the restoration of forests, Brazil. Scientia Forestalis, Piracicaba, v. 46, n. 119, p. 415 - 426, 2018.

LORENZON, A. S.; DIAS, H. C. T.; TONELLO, K. C. Escoamento da água da chuva pelo tronco das árvores em uma Floresta Estacional Semidecidual. Revista Árvore. Viçosa, v. 39, n. 3, p. 423 - 430, 2015.

LUNA-ROBLES, E. O.; CANTÚ-SILVA, I.; GONZÁLEZ-RODRÍGUEZ, H.; MARMOLEJO-MONSIVÁIS, J. G.; YÁÑEZ-DÍAZ, M. I.; BÉJAR-PULIDO, S. J. Nutrient input via gross rainfall, throughfall and stemflow in scrubland species in northeastern Mexico. Revista Chapingo Serie Ciencias Forestales y del Ambiente, Chapingo, v. 25, n. 2, p. $235-251,2019$.

MELO NETO, J. de O.; MELlO, C. R.; MELlO, J. M.; GUIMARÃES, D. V. Comportamento físico da precipitação interna em um povoamento de Eucalyptus. Ciência Florestal, Santa Maria, v. 29, n. 3, p. 1215 1226, 2019.

MOURA, A. E. S. S.; CORREA, M. M.; SILVA, E. R.; FERREIRA, R. L. C.; FIGUEIREDO, A. C.; POSSAS, J. M. C. Interceptação das chuvas em um fragmento de floresta da mata atlântica na bacia do Prata, Recife - PE. Revista Árvore, Viçosa, v. 33, n. 3, p. 461 - 469, 2009.

MOURA, A. E. S. S.; CORREA, M. M.; SIlVA, E. R.; LIMA, G. S.; SENA, J. R.; FIGUEIRÊDO, A. C. Precipitação efetiva nos períodos chuvoso e pouco chuvoso em um fragmento de Mata atlântica, Recife - PE. Revista Brasileira de Recursos Hídricos, Porto Alegre, v. 17, n. 7, p. 7 - 16, 2012.

QUEIROZ, A. T.; OLIVEIRA, L. A. Relação entre produção e demanda hídrica na bacia do Rio Uberabinha, estado de Minas Gerais, Brasil. Sociedade \& Natureza, Uberlândia, v. 25, n. 1, p. 191 - 204, 2013.

SHAPIRO, S. S.; WILK, M. B. An analysis of variance test for normality. Biometrika, Cary, v. 52, n. 3 - 4, p. $591-611,1965$.

SILVA, A. C. F.; SOUTO, J. S.; SANTANA, J. A. S.; SOUTO, P. C.; NASCIMENTO, J. A. M. Distribution of Rainwater by species of caatinga vegetation. African Journal of Agricultural Research, Lagos, v. 13, n. 41, p. $2239-2248,2018$.

SILVA, F. A. S.; AZEVEDO, C. A. V. The assistat software version 7.7 and its use in the analysis of experimental data. African Journal of Agricultural Research, Lagos, v. 11, n. 39, p. 3733 - 3740, 2016. 
TEDESCO, M. J.; VOLKWEISS, S. J.; BOHNEN, H. Análises de solo, plantas e outros materiais. $2^{\text {a }}$. ed. rev. e amp. Porto Alegre - RS: UFRGS, 1995. 174 p. il. (Boletim técnico, 5).

TONELlO, K. C.; GASPAROTO, E. A. G.; SHINZATO, E. T.; VAlENTE, R. O. A.; DIAS, H. C. T. Precipitação efetiva em diferentes formações florestais na Floresta Nacional de Ipanema. Revista Árvore, Viçosa, v. 38, n. 2, p. $383-390,2014$.

UCHIYAMA, R.; OKOCHI, H.; KAMIYA, J.; ASAI, D.; KANEKO, C.; OGATA, H.; KATSUMI, N. The impacts of "urban-induced heavy rains" on the distribution of deposition fluxes of inorganic acidic substances in the Tokyo metropolitan area in summer. Atmospheric Research, [S.1.], v. 200, n. 1, p. 109-116, 2018. 